Article

\title{
Sàng khôn as A Theorizing Tool in Mobility Education
}

\author{
Ngoc Ba Doan
}

School of Education, University of South Australia, St. Bernards Road, Magill, SA 5072, Australia; ngoc.doan@unisa.edu.au

Academic Editor: Michael Singh

Received: 3 November 2016; Accepted: 25 January 2017; Published: 8 February 2017

\begin{abstract}
The current virtual and physical mobility of humans, ideas, knowledge and epistemologies has major implications for education, especially in settings where English is seen as the default medium of instruction. While diversity is inherent in mobility, English-only pedagogy is a denial of the richness and potential of diverse resources learners bring with them through their mobility. This paper reports a philosophical stance and pedagogical practices employed by a lecturer in English language education at an Australian university. It argues that students' full linguistic resources and epistemologies, known as sàng khôn, contribute to their agency and can be used as tools to theorise new knowledge in the context of their mobility education.
\end{abstract}

Keywords: sàng khôn; translanguaging; multilingual resources; bi-/multi-lingual education; English as a medium of instruction (EMI)

\section{Introduction}

Mobility education is contesting pedagogies which refuse to recognize the value of international students' linguistic and cultural resources in their construction of new knowledge [1-11]. In this paper, mobility education is understood as education pursued by international students through their global mobility, both physically and virtually. Mobility education is a phenomenon of globalisation which is understood as intensified and inter-influenced sociocultural, economic, technological and political relations across the globe [12]. Embedded in that global network of relationships are transnational flows of international students and their cultural, linguistic, and cognitive resources. Estimates from Project Atlas indicate that by 2012, as many as 4.5 million students had travelled to pursue higher education in countries outside their own [13]. Many of them are fulfilling, or doing their best to chase, their dreams of studying in English-speaking countries. Of the top eight host destinations for international students in higher education in 2014, the US, the UK, Australia and Canada accounted for $45 \%$ of total international students [13]. In Australia, by June 2016, there had been 448,411 international students studying at all levels of education [14]. There are several reasons for this strong preference for these destinations. First, they are home to the top-ranked universities in the world. Of the top 25 universities in the world, 24 are from these English speaking countries [15]. Second, students expect to be able to improve their English language skills-the global language [16]. Therefore, being able to study in these destinations, students have opportunities to experience quality education and simultaneously to develop their English proficiency.

Mobility education is globalising host institutions and classrooms, turning them into "contact zones" $[17,18]$. Within these zones, educators and international students meet and interact, as do their cultural, linguistic and cognitive resources through processes known as cultural flows [18]. These flows are influencing and changing classroom practices in higher education institutions and placing educators in pedagogical "dilemmas between their professional ethic of cultural respect and the curricula of linguistic-cultural orientation to Western higher education" [18]. The use of students' 
cultural and linguistic resources as tools for their knowledge production and theorisation in these flows is being investigated $[8,17,19]$. As Singh and his colleagues observe:

While their mobility may be obvious, certain aspects are obscured. For instance, whether these mobile students' languages and knowledge-their concepts, metaphors and images-are purposively, systematically and strategically being deployed to reconstitute seemingly local, place-bound educational cultures is less apparent. [8]

The deployment of students' resources for theorizing new knowledge is becoming a hotly debated topic in higher education when students are more mobile than ever before. In the following section, I will briefly discuss the role of mobility in education by revisiting the etymological underpinning of the term theorization. I will then explicate a Vietnamese concept, sàng khôn, as an example of a Vietnamese tradition to embrace relationship between mobility and education.

\section{Mobility, Knowledge Theorization and the Vietnamese sàng khôn}

The role of mobility in knowledge theorization has long been recognized in human history. Etymologically, theorisation is from Greek theôria, which means contemplation, speculation, and spectator (http:/ / www.oxforddictionaries.com/definition/english/theory). Theôria reflects Greek philosophy in learning and knowledge production [20]. The essence of "theôria" is that one departs one's home to travel and come back with new knowledge and disseminate it to his/her community. According to Nightingale [20], there are three varieties of theôria. The first two share the principle that one is sent by his/her community to an oracle or a religious festival to consult with the oracle or learn from the festivals then comes back to his community with new knowledge. The third variety asserts that theôria means sending a person to a foreign country but not necessarily to a religious figure or festival to learn new knowledge. This variety sees religion as not the only source of knowledge. As such, theôria values travelling and witnessing as central to knowledge production. In other words, through mobility knowledge is constructed.

Mobility is well regarded in the Vietnamese philosophy of education. Tran and Marginson [21] comment that it is "a dimension of Vietnamese tradition" for learning and becoming.

The virtue of mobility has been nurtured in Vietnamese life and is particularly embraced in our aspiration to enrich knowledge and develop a well-rounded human being [21].

A well-rounded human being is one who travels far and wide and enriches his/her knowledge while traveling, hence education through mobility. According to Tran and Marginson [21], mobility should not be limited to being physically mobile but also virtually mobile. Thanks to modern technologies, both physical and virtual mobility are becoming increasingly possible and easy. Mobility can also be understood in terms of human mobility, idea and knowledge mobility, and skills mobility [21].

Through mobility, one has opportunities to explore lived experiences in different local contexts to learn. By contrast, when one is immobile, he/she loses such opportunities to become wise. Once information and internet technology was not imaginable for Vietnamese people, being immobile means confining oneself to home environment.

Đi cho biết đó biết đây, ở nhà với me biết ngày nào khôn. (Literal translation: Travelling to get to know here and there, confining oneself to home one will never know when to become wise).

The importance of mobility is also reflected through contrasting image of immobility: Ế ch ngồi đáy giêng (Literal translation: Frogs sitting at the bottom of a water well). The saying is used to refer to someone who has very little or limited knowledge due to being immobile. What a frog sees while sitting at the bottom of a water well is a round piece of heaven which is afforded by the walls of the well. A piece of heaven is not heaven. Here heaven represents the outside world and the source of "trí khôn" (wisdom). Only getting out of the confined walls of the water well and travelling wide and far in the heaven, can one learn to become wise. 
A characteristic of Vietnamese proverbs is that they are theorised out of ordinary people's life experiences from generations and theorising; they are lessons or advice to teach people how to do things [22]. In other words, there are always philosophical stances embedded within Vietnamese proverbs. A philosophical stance of mobility education reflected in the above proverbs is learning from reality and diversity. This is explicitly reflected in trăm nghe không bằng một thấy (Literal translation: A hundred times hearing is not as much as once seeing/witnessing). Learning should not be limited to classroom, but also through participating in daily life activities with people in their communities [23]. Travelling affords learners opportunities to in contact with new realities and new people in their social and cultural communities.

These characteristics of mobility education is evident in the proverb đi một ngày đàng học một sàng khôn (literal translation: Travelling one day on the road, one learns a basketful of wisdom). The Vietnamese sàng khôn (basketful of wisdom) is developmental and reflects the agency of learners in their developmental process. Sàng khôn is developmental in that when a new day comes one comes with an increased amount of wisdom and as a result a new self or enriched identity [24]. With increased sàng khôn, one will "reassess [his/her] sense of [self] and [his/her] desire for future" [24]. Therefore, sàng khôn, on the one hand represents learners' ever enriching identity, and on the other hand, the investment they have to build up their future identity. Understood as such, sàng khôn is ever becoming and diverse and is attributive of and resource potential for learners. It is their identity and investment for their self-fulfillment and becoming.

Sàng khôn represents knowledge and resources one has learned, contemplated and theorised. In this sense and for the purpose of this paper, sàng khôn is defined as learners' whole cognitive, cultural and linguistic repertoire and skills they have developed through mobility which are potential resources for their future becoming. In this definition, mobility, understood as above, is a crucial factor in the development of sàng khôn. Constructed through mobility, sàng khôn is diverse in nature.

This definition may suggest a possible similarity between sàng khôn and funds of knowledge [25] which refer to "historically and culturally developed bodies of knowledge and skills essential for household or individual functioning and well-being" [26]. Both are knowledge and skills accumulated throughout one's life history which serve as tools for one's further knowledge construction. Research into funds of knowledge was first initiated in late 1980s as a result of the observation that knowledge and skills Spanish-speaking students accumulated in their household were not capitalised on in the mainstream (English mediated) schools in San Diego [27]. In other words, funds of knowledge are house hold knowledge [26]; or knowledge and skills accumulated throughout the history of the house hold. By contrast, sàng khôn is constructed throughout one's life history in his/her mobility. In this sene, funds of knowledge and sàng khôn are not the same. Sàng khôn is inclusive of knowledge and skills one learned from home, schools and diverse communities and is resource for use in one's further education.

\subsection{Use of sàng khôn in Education}

Using students' sàng khôn has long been advocated in bi/multilingual education [4,5,9,28-31]. In recent decades the use of sàng khôn is referred to as translanguaging. Linguistically, the term translanguaging is constructed from three morphemes: the root language and two bound morphemes trans- and -ing to indicate the meaning of process of moving across or beyond or surpassing languages. This meaning is evident in all the definitions below.

[T]ranslanguaging refers to the deployment of a speaker's full linguistic repertoire, which does not in any way correspond to the socially and politically defined boundaries of named languages. [32] (italics originals)

It is a linguistic practice that involves different languages and language varieties but more importantly a process of knowledge construction that makes use of but goes beyond language(s). [7] (italics original) 
Translanguaging is the process of making meaning, shaping experiences, gaining understanding and knowledge through the use of two languages. [33]

The ability of multilingual speakers to shuttle between languages, treating the diverse languages that form their repertoire as an integrated system. [34]

Language is central in all these definitions. There are differences, however, in what language is. García and Kleyn [32] view language, from the speaker's internal point of view-that is, a resource whole for meaning making which does not discriminate one from another. Their view is explicated as follows:

The term translanguaging should be taken in the sense of transcending, "going beyond", the two languages of bilinguals ... or the three of trilinguals, or the many of mutlilinguals, and to think of bilinguals/multilinguals as individuals with a single linguistic system (the inside view) that (the outside view) calls two or more languages. [32] (italics \& double quotation marks original)

So entities such as English or Vietnamese are seen as countable from the outside view, while the social representation of the inside linguistic whole is not countable. In other words, inside a bilingual or multilingual, there is no discrimination between English and Vietnamese; instead they feed into a linguistic whole which has potential for use. For García and Kleyn, pluralisation of language is politically loaded and represented. This view is echoed in another publication García and Li Wei co-author [5] in which they make clear that translanguaging transcends the boundaries of countable languages defined by the nation-states. In this publication, García and Li Wei expand translanguaging beyond the use of language to include other semiotic resources. In other words, the meaning of language in translanguaging is not confined to linguistic resources but other modes of communication; or multimodal which is reiterated in Li Wei's definition above. In this sense, the resources used for translanguaging have the meaning closest to sàng khôn.

Both Li Wei and Baker place special emphasis on translanguaging as the process of knowledge construction. Drawing on what Li Wei and García argue above, translanguaging is the process in which leaners' sàng khôn is used as resources for their knowledge construction. Their views of translanguaging, therefore, problematize English-only policy and practices in mobility education (See, for example, $[1,3,9,10])$.

From a different point of view, Canagarajah [34] defines translanguaging as the speaker's ability to deploy and alternate languages within linguistic repertoire. Like Li Wei, García and Kleyn, Canagarajah treats multilingual speakers' linguistic repertoire as a unified whole. His view of translanguaging, however, differs that of Li Wei and García [5] in the exclusion of the use of semiotic resources other than languages. He reserves the term "codemeshing" for the inclusive use of all these resources.

Unlike translanguaging, codemeshing also accommodates the possibility of mixing communicative modes and diverse symbol systems (other than language). [34]

Whether understood as a process or ability, translanguaging is never separated from sàng khôn. In fact, they are integral in mobility education. Through translanguaging, learners' sàng khôn is activated and used as tools for their knowledge construction and theorisation. The use of sàng khôn is problematizing English-only policy and practices.

\subsection{English-Only Pedagogy and Learners' sàng khôn}

Informed by research into bilingual and multilingual education, scholars have been contesting English-only pedagogy and advocating the use of learners' sàng khôn in mobility education [1-11]. Auerbach [9], for example, argues that English-only pedagogy is ideologically rooted and driven by political power. The ideological perspective is described by Phillipson [10] in terms of five tenets as follows: 
- Tenet one: English is best taught monolingually;

- Tenet two: the ideal teacher of English is a native speaker;

- Tenet three: the earlier English is taught the better the results;

- Tenet four: the more English is taught, the better results;

- Tenet five: if other languages are used much, standards of English will drop.

Phillipson [10] argues that these tenets are Anglo-centric and are maintained to reinforce the power of the Centre over the Periphery.

They secure a bridgehead for the Centre in the Periphery, thereby legitimating Centre export of 'experts', know-how, projects, books, etc. and securing the imperialist penetration of the education systems of the emerging post-colonial states. [10]

From an educational point of view, Swain, Kirkpatrick and Cummins [4] argue that English-only pedagogy results from a monolingual policy which posits that multilinguals' primary languages interfere with the target language and that language learners should be exposed to the target language as much as possible. As a result, teachers and learners try to keep primary languages away from the target language as much as possible and deliberately avoid using the former for the development of proficiency in the latter [4]. Scholars have disputed this monolingualist view by arguing that multilinguals are not multiple monolinguals in a single brain [11]. Instead, languages spoken by multilinguals are interdependent and once learned, they feed into what Cummins [28] refers to as a Common Underlying Proficiency (CUP) and are facilitative for each other's development and for knowledge production $[4,28]$. This proficiency is part of learners' sàng khôn.

Reflecting on the situation of mobility education in higher education, Singh [3] shares Auerbach's observation and claims that English-only pedagogy is taken for granted in mobility education and is dominant in teaching and generating theories at Anglophone universities. Informed by research he has conducted alone and with colleagues over the past decade, Singh $[2,8]$ argues that English-only pedagogy rejects the mobility of people and ideas and ignores international students' linguistic and cultural diversity, their prior skills and knowledge (or sàng khôn) while promoting English and Anglophone modes of critical thinking as defining features of international education. In so doing English-only pedagogy puts international, especially Asian, students in the same stigmatised baggage of being

'dependent', 'hierarchical', 'collectivist', 'reticent', 'indirect', 'passive', 'docile', 'lacking in self-esteem', 'reluctant to challenge authority', 'easily dominated', 'undemocratic', or 'traditional' and, in effect, uncritical and unthinking. [35]

In other words, this pedagogy ignores learners' sàng khôn and denies their agency in their knowledge construction and theorisation. At an individual level, English-only pedagogy places international students in "an unequal position with their monolingual English-speaking peers" [2] and restricts "the use of their full theoretic-linguistic repertoire" [3] in their learning and knowledge production. At an institutional level, English-only pedagogy "invites Anglophone universities and multilingual students to imagine that English is the only language in which modern, innovative knowledge is produced" [2]; therefore, Anglophone universities with English-only pedagogy "fail to recognise and accredit similar modes of theorising undertaken in non-Western languages" [3]; hence failing to recognise learners' agency in their quest for knowledge and theorisation in mobility education.

Singh also observes that researchers "are working to affect shifts in the languages and theorisation of mobility education" [3]. Like Auerbach [9], Singh emphasises that what he and other scholars are doing regarding mobility education "does not mean the denial of English-only theories but rather [advocacy for them] to be tested along with many others" [3]. In other words, they are creating a space for international students to critique English-only theories and knowledge production against what 
they have and know in their languages using their sàng khôn—the criticality of sàng khôn [5]. This paper now presents one of such efforts in using and encouraging learners to use their sàng khôn as tools for knowledge construction and theorisation in their studies at an Australian university.

\section{Research Design and Context}

The informant in this study is referred to as Mary. Mary is an Associate Professor in Applied Linguistics, who has a doctorate in bilingualism. She has extensive experience in English language teaching and language education policies in different parts of the world, especially in Australia, Russia, different parts of Europe, Asia and Africa. Mary is a native speaker of English as defined by Braine [36] and can speak some other African languages. Mary designs and teaches undergraduate courses in English for academic use, language studies and language diversity. The students referred to in this study came from English as an additional language backgrounds who were enrolled in various disciplines within the university, and were studying English for their academic use in Australia. Most of them were speakers of Chinese Mandarin and other Asian languages. Mary did not speak their languages.

The data for this paper were sourced from Mary's responses to a mini questionnaire survey I conducted in June 2015, a follow-up in-depth interview with her a year later, and the curriculum documents from a course she was teaching. The initial questionnaire was carried out for my presentation at a local research group conference: Placing Global Englishes in Class. The sub-theme for the strand in which I presented was One English or Many Englishes? Language Diversity in the Classroom. The questionnaire was emailed to five senior lecturers in English language education who were working at three universities in Australia. These lecturers had had extensive English teaching experience across Kachru's [37] inner, outer and expanding circle contexts, especially in the Asia-Pacific region. It was a mini survey because it had only one question which sought to identify teaching practices the participants adopted in their classes.

As part of the arrangement for the interview I sent Mary an interview guide with 15 points I wished to explore. This served to provide her with key points for the interview while it allowed me flexibility to probe into certain points of interest. The guiding points were structured to seek information about the pedagogy she was using, what informed her pedagogy and how it could assist students to develop their proficiency in academic English.

A week after the interview I sent Mary my interview transcript for her verification of the accuracy of the information, and soon received it back with some minor changes. However, while analysing the interview and questionnaire data, I saw the need to obtain further concrete information about the courses-for example, the weekly topics and assessment. I decided to contact her again for some course curriculum documents. Mary emailed me the outline and assessment documents for the course. This is a full-semester course where students have 133 -hour weeks of face-to-face lectures and tutorials. The information collected from the questionnaire, the interview and the curriculum documents is used to illuminate the question below.

In what ways is undergraduate students' sàng khôn used to facilitate their development of proficiency in English and their knowledge production at an Australian higher institution?

The analysis of the data was guided by the understanding of sàng khôn and translanguaging as discussed. Students' mobilization of their cognitive, linguistic and cultural resources to theorise new knowledge is the act of translanguaging. For the analysis, I used Microsoft Word and Excel to identify themes that emerged from the interview. The use of Excel was to allow flexibility of grouping and re-grouping themes and the corresponding information. Information from the course curriculum documents was used to illuminate the analysis of the interview and questionnaire data. In this paper, all quotes are from the interview, unless otherwise stated to be from questionnaire or curriculum documents. The following section presents the key themes identified, which begins with Mary's view of multilinguality—a theoretical understanding which informs her teaching practices. 


\section{Multilinguality and Working with Students' sàng khôn}

For Mary, working with students in the contact zone in higher education institutions in Australia was working with multilinguality. She explained her idea of multilinguality as follows.

I think about language/s in terms of multilinguality. The distinction between one English and another and one language and another is not clear to me. Is English English? If one considers that corpus of English-how much of this is English? How much of this comes from other languages? (Questionnaire)

The language repertoire may include another so-called form of Global Englishes or it may be Mandarin, Vietnamese and so on. It is likely to mean a degree of hybridity of the home language and English. For me this is a dimension of multilinguality. (Questionnaire)

Multilinguality represented both the hybrid nature of language in multilingual settings and students' whole linguistic repertoire which includes their primary languages and their current English proficiency. In addition to this linguistic repertoire, students' epistemologies were also recognised and used.

Epistemology is the knowledge system. For instance in Africa, if one goes to a little village in a remote area, people will know a great deal about how the world works. They'll know about the environment, they will know about when to plant, what to plant, what animals will survive there, how they will survive, how to actually live in a sustainable way within that particular setting. So they develop an epistemology. If one goes to any indigenous Australian community, the community will know and pass on knowledge from generation to generation of how to live in a sustainable way in what appears to be very arid and difficult circumstances. So this is knowledge. This is really significant knowledge.

Mary's view of multilinguality-linguistic hybridity and epistemologies-mirrored the concept of sàng khôn. She argued that multilinguality was resource for learning, so she found ways to apply it in her teaching of English to her students.

I am trying to build a strong pedagogy in which I understand that students bring their own linguistic repertoires (and epistemologies) into the classroom and that in order to further develop their English for academic life in Australia, they need to use their repertoire (the whole repertoire) and their own epistemologies. (Questionnaire)

In her pedagogy, Mary encouraged students to mobilise their sàng khôn to theorise new knowledge. Mary referred to this mobilization process as translanguaging; however, conceptualized it differently from other scholars.

\section{Multidirectional Translanguaging}

When invited to elaborate on her definition of translanguaging, Mary said:

If I were to define translanguaging I would say that it is a key aspect of multilingual education. And by translanguaging I would suggest that it is a blanket term which covers practices of code mixing, code switching, translation, interpreting; that it is not one directional, that it is multidirectional.

Mary's view shares fundamental understanding of translanguaging as discussed earlier; that is the practices that involve the use of different languages. She added that translanguaging originated from Wales where it was used to refer to "systematic use of code switching" in which "students would begin a text in one language and then they would be asked to write the text in a second language, and then to switch back to the first language and then to continue again in the second language; in other 
words, very systematic use of two languages in their learning and also in their demonstration of their ability to use two languages and to be bilingual."

So working with different languages was only one aspect of the Welsh translanguaging. Another important feature was that students were expected to develop their proficiency in both or all languages that they worked with. Using this feature, Mary conceptualized translanguaging in two categories, Global North and Global South.

\subsection{Global North ws. Global South Translanguaging}

For Mary, Global North translanguaging is currently initiated and practised in bi/multilingual education in the US and UK where Kachru refers to as inner circle countries (IC) in which English is the primary language of communication. She provided several examples of Global North translanguaging practices as follows.

- Use of students' home language in the process of developing high level of proficiency in English [in the US]; or

- Community-based projects [or] adult education projects [in the UK, where] women ... use their primary language to develop their literacy skills which will take them towards proficiency in English.

The translanguaging practices in the Global North share a common feature which is students using their linguistic repertoires and knowledge systems to develop their proficiency in English-the target language. Mary explained:

In the US context, this is the target-the target is English. It's not a bilingual target. The mainstream approach is toward English to get all the minority communities to become proficient in English. So translanguaging in the US or North American context very often may be interpreted as one directional from the home language or the minority language towards the majority language. This sort of particular uni-directionality seems also to be very much part of the discourses of some of those who are writing about translanguaging in the UK. (Italics added for emphasis)

Translanguaging practices in the Global North are sharply distinct from those practised in Wales. While the latter are multidirectional and aim to develop students' proficiency in both languages, the former are unidirectional and aim to develop students' proficiency in English-the majority language of the society. Using students' linguistic resources is a means to an end; that is students are able to speak the target language so that they can integrate into the wider society. However, developing students' proficiency in their indigenous languages does not form part of this end.

By contrast, the Global South context is sharply different which brings implications for the nature and purposes of translanguaging.

For most settings in the Global South, [English] is a de facto minority language; very few people speak that language. It is the language of great prestige. It is the language through which power is channelled.

The difference is informed by the role the target language, or English, plays in these societies and the purpose for learning it. English is not the language but rather an additional language for communication. Mary provided South Africa and India as examples where English is a language of power and prestige and spoken by a small number of local people. These are countries in Kachru's outer circle (OC). Here English may afford its speakers social advantages, like "the opportunity to go to university". However, these are added values for those who are able to speak it as an additional language while still maintaining their major language(s). In other words, in these countries, learning English is to be bi/multilingual. In other contexts like China, Viet Nam, Japan or Korea-the countries 
in Kachru's expanding circle (EC)—English is not even a language for communication in the wider society. Many people are learning the language for international communication only. There may be real or imagined social values, for example, job opportunities or studies abroad $[38,39]$. The language people use most frequently in these countries is their national language, possibly plus one or some other ethnic languages.

Therefore, in the Global South context people are not driven to learn the language of the society as a requirement for their full integration into it. Their learning of English is to become bi/multilingual. On this account, Mary argued

In China, Viet Nam, Korea, Japan, India, Africa, you've got a majority of children who are being channelled towards English, which is the minority language. They cannot possibly learn English using the same pedagogies that are used in the US or in the UK. We have to understand that these are completely different circumstances and it cannot be seen as it is a one directional process. It has to be multidirectional.

The pedagogy Mary was building was multidirectional in this sense-for learners to develop their proficiency in English and their primary languages-the Welsh multidirectional translanguaging or Global South translanguaging. She strongly asserted:

So when I refer to translanguaging, I do not refer to it in the same way as understood by some of my colleagues in the US. I refer to it as a much bigger project of multilingual education. I see it as multi-directional and I think that it is really important for students to develop a high level of proficiency in the strongest proficiency of their primary community.

She related this to her students:

So for international students coming here, they need to develop their functional bilingualism, in their home language and in English, in order to be able to function both in Australia and in the home country. So they would need to be able to know how to move between the two languages and make whatever accommodation and changes that are necessary. And also to be clear about how they are doing that. But the more they develop their metacognitive awareness of how they're doing that the stronger will become both, and also their sense of their language proficiency.

This comment indicates that Mary's translanguaging may have effects beyond multi-directional proficiency to regain learners' agency through the use of their own indigenous languages and knowledge to produce new knowledge. This raises a pedagogical question as to how Mary initiated her Global South translanguaging in her classes, especially when she did not speak her students' languages.

\section{Global South Translanguaging: How the Pedagogy Works}

In Mary's view, translanguaging in language learning was characterised by the practices of using learners' languages and English as well as the knowledge systems and expertise retained in learners' linguistic repertoires to facilitate their proficiency in the target language as well as in their primary languages. Translating between languages, cross-referencing and embedding translanguaging in genre pedagogy are practices Mary applied in her pedagogy.

\subsection{Translating between Languages}

Throughout the course, Mary asked her students to engage in a number of translation activities between their primary languages and English (the target language). This was set up as part of the course activities and as part of students' preparation for their assessment. Translating activities took on the following forms:

- Students translated course readings into their primary languages; 
- Students wrote their essays in their primary languages(s) then translated them into English or vice versa;

- Students took notes in their primary languages or alternated their note-taking between their primary languages and English.

In her research project with Mandarin and Cantonese speaking students, Mary was able to collect "over 1000 pieces" of writing in primary languages or combining English and their primary languages. Mary asserted that the purpose for having students translate between their primary languages and English was to make sure they understood the texts and more generally the course content. Once they sufficiently understood the course content, they would be able to "address the assessment requirement", "demonstrate their ability to be able to graduate", and "conceptualise their understanding of the course content".

Mary insisted that her students engage in two-way translation, that is, translation between their primary languages and English, and avoid word-for-word translation. The message she often conveyed to her students is that.

When you convert it or translate it, it can't be word-for-word translation. You are going also to have to translate it in the way that it matches the form and structure of academic English.

To this end, after students translated from their primary languages into English, she asked them to edit and rewrite their translated versions in English.

I expect the students to do some translation and also to try to edit their translation so that they are not necessarily limited to direct translation, but they understand the process of translating and then rewriting and editing in order to match the idiomatic expression or the structural dimensions of the target language.

So the written piece of writing that students were expected to produce was not just in English but in grammatically and idiomatically structured English.

Mary found from her research that students with low levels of proficiency in their primary languages were more often involved in word-for-word translation and that through translation, students stood a good chance of improving their proficiency in their primary languages as well.

It is important for them to try to expand and further develop their academic proficiency in the primary language while simultaneously doing the same in English.

So, for Mary, engaging in translation activities between languages serves dual purposes: that is for her students to develop their proficiency in both English (the target language) and their primary languages. Another way of translanguaging Mary utilized in her classes was having her students use and cross reference the knowledge encoded in both English and the languages they speak.

\subsection{Cross Referencing Knowledges}

In research tasks, Mary required her students to read and share knowledge systems that were written in their primary languages and test them against those in English and reference them in their research reports.

There may be a research topic that students have to go away and read about but I do not expect my students to read academic texts only written in English; I expect them also to supplement the core reading texts in English with research material and other evidence that they are able to source in their primary language so that they are able to cross reference and at least find ways of engaging and using them-the knowledge and expertise that they have in their primary language- - to assist their conceptual knowledge and use of this information in English. 
I am encouraging students to use their whole linguistic repertoire wherever this is appropriate in order to be able to grasp the kind of research material, evidence, information that may be useful in the writing of different types of essays or research reports.

Here not only students' primary languages and English but also their indigenous knowledges and epistemologies were used as tools to illuminate and interpret research data and to create their new knowledge. Two important pedagogical implications are noted here. First, students' indigenous knowledges and epistemologies were recognised as valid interpretive and analytical tools in their quest for new knowledges. Second, through cross-referencing using knowledges and epistemologies students found in English and in their primary languages, students had opportunities to critique and test the two system of knowledges and epistemologies; this is not found in English-only pedagogy [3]. These implications suggest that in Mary's pedagogy, students' sàng khôn is deployed as theorising tools in their knowledge construction $[3,17]$ to illuminate and interpret their research findings.

Mary consistently insisted that knowledge "tightly held" in students' primary language systems was to be "unlocked" and made "portable across the whole linguistic and cognitive faculties or capabilities". This amount of knowledge is huge considering the number of languages in the world.

There are over 7000 languages in the world. But the knowledge retained in over 7000 languages of the world is not transported through the very few languages that are controlled by the academy. In 1970 the languages used in the academy were French, German, Spanish, English, Italian and Portuguese, 6 languages. We've got to the point now, 2016, when most of what is written in academy is in English. It was bad enough when it was filtered through just six imperial languages. But the amount of knowledge published academic texts in the six now has shrunk to mostly in one. Now what are we missing? There's a huge amount of knowledge and expertise simply being missed as it's not been captured.

Mary strongly asserted that not only are such systems of indigenous knowledges and epistemologies to be transported between individual members in her class, they are to be accredited at an institutional level.

If we're doing our jobs properly at universities, we would be wanting to access whatever knowledge our students bring to us and also to share not only for their benefit but also for our benefit and also for the benefit of all students at the university so that we are able to share the knowledge, the epistemological knowledge that students are able to bring from whatever country they come from in order to enrich all of our courses.

This comment is projected to institutional accreditation of students' indigenous knowledges and epistemologies in an English-medium educational setting. This accreditation is to begin with staff members in their classrooms.

What we're trying to do is to allow students to become aware that they are all resources, they all have access to epistemological expertise and that together we might be able to access that knowledge in order to be able to better understand other people, to be able to communicate across cultural divides. And what we're hoping to do this year is to not only do that but to bring in a linguistic dimension to that so that students are more aware of the language and the epistemological expertise that they can have in order to enrich their intercultural capabilities while at university.

When the English-only pedagogy is so well-entrenched [40], teaching staff are to make students aware of the values of their indigenous knowledges and epistemologies and that it is valid for them to use such knowledges and epistemologies in their journey of constructing new knowledge. 
And I have found that students have been surprised that I have encouraged this process and have intimated that they had thought that this would not be an acceptable process.

On account of that I have now made it a specific requirement that in all of my assessment items I would like to see lists of references that include mainly references in English but also references in at least one other language. And I found that students have responded really well to this.

In so doing, Mary was empowering her students to bring such systems of knowledges and epistemologies to classroom and share them with their class fellows and staff; another effort in assisting students to regain their agency through the activation of their full sàng khôn in their quest for new knowledge. Mary insisted that for her students to well develop their proficiency in both languages, translanguaging practices should be embedded in the learning of different genres of text. This suggests the use of translanguaging with genre pedagogy.

\subsection{Translanguaging Embedded in Genre Pedagogy}

Mary was using genre pedagogy [41] in her teaching of English to her undergraduates, since she found that having students understand the "large structure of different forms of text" was very helpful for them. The students were provided access to different text types, especially those they would encounter in their academic studies (See Table 1 for examples of genres used in her course). She said "I'm using genre but also I'm able to use translanguaging within genre."

Table 1. Course schedule.

\begin{tabular}{cl}
\hline Week & \multicolumn{1}{c}{ Content } \\
\hline 1 & Introduction to Course \\
2 & Reflective Writing and Autobiography \\
3 & Biography and Film Review \\
4 & Features of Biography and Politeness \\
5 & Biography and Grammar of Biography \\
6 & Biography, Research Methodology and Grammar in Context \\
7 & Descriptive Writing \\
8 & Descriptive Writing \\
9 & Oral Presentation Skills and Australian English \\
10 & Oral Presentations, Indigenous Australian in Australian Film and Literature \\
11 & Preparation for Grammar Test and Oral Presentations in Class \\
12 & Preparations for Final Grammar Test and Oral Presentations \\
13 & Final Assessment: Grammar test, Evaluation and Farewell \\
\hline
\end{tabular}

Notes: Adapted from the Course Outline.

Below is a snapshot of the course outline to show how the genre teaching is included in the course.

The course introduces students to four different text types: reflective writing, biography, film review, and descriptive writing. These text types form the skeleton of the course around which other course content is structured and offered, including grammar features of each text type, research skills and presentation skills. The course assessment is also structured around these text types in order to have students to develop both linguistic and discourse competence as part of their communicative competency [42].

\section{Discussion and Final Remarks}

So far I have argued that the Vietnamese sàng khôn is both resource and tool for knowledge construction and theorisation in mobility education. Ontologically, sàng khôn is similar to funds of knowledge [26] as both refer to the repertoire of knowledge, skills and ways of doing people construct and accumulate throughout their life history. Epistemologically, sàng khôn is different; it is constructed 
from diverse realities which are afforded by mobility. Funds of knowledge are household knowledge constructed out of household history [26] while sàng khôn is theorised throughout human mobility. With multiple types of mobility [21], the repertoire of sàng khôn is inclusive of knowledge and skills one learns from home as well as those he/she learns from schooling and travelling wide and far.

Sàng khôn and the process through which it is activated represents students' agency. Sàng khôn is students' identity they construct out of their mobility education which, in turns, affords them resources for their continued well-rounded becoming. Through translanguaging, students' sàng khôn is activated. Also, through this process, students realise the values and potential of their sàng khôn in the theorization of new knowledge. It is this process that they initiate flows of their indigenous knowledge systems to the mainstream educational contexts. This is much needed evidence to validate the values of indigenous knowledge- the Southern theory in the Northern-Southern theorization debate $[43,44]$.

Mary's conceptual construct of Global South translanguaging is a contribution to the contestation of one-way flow of knowledge from Global North to Global South. Her view of Global North and Global South is respectively associated with Kachru's Inner IC societies where English is the primary medium of communication and instruction and OC and EC societies where English is not. In the latter societies, English can be $a$ medium of communication and/or instruction. On the one hand, Mary's Global South translanguaging provides empirical evidence that there are knowledge systems encoded and available in students' sàng khôn who come from Global South contexts. On the other, Global South translanguaging can instigate the flow of knowledge from the Global South to Global North context. In other words, Mary's Global South translanguaging practices problematize the proposition that OC and EC societies in the Global South are unable to create knowledge. Instead, they are consumers of knowledge created in the Global North and sources of data for knowledge creation in English in IC societies in the Global North $[8,43,44]$. This is Mary's philosophical stance on translanguaging, which contributes to the North-South theory debate [45].

In addition, Global South translanguaging practices have useful implications for mobility education in general and for English language teaching and learning in particular.

- Global South translanguaging to develop students' multilingual proficiency: In Global South translanguaging, students activate both English and their primary languages with the purpose of developing their skills in both English (the target language) and their primary languages. This is much needed in global mobility, where international students are on the move between their home and host countries and especially where the labour market is no longer defined by the confined boundaries of physical spaces [46].

- Global South translanguaging to be embedded in genre pedagogy: This is to make sure that students are exposed to the genres (i.e., text types) and linguistic features specific to these genres which are commonly found in different disciplines students specialize in. Translanguaging allows students to explore, compare and contrast these textual features between English and their indigenous languages in order to develop their multidirectional language proficiency.

- Global South translanguaging to facilitate students' knowledge construction and theorization using their indigenous knowledges and epistemologies: An intended pedagogical practice in Mary's translanguaging is to unlock students' indigenous knowledges and epistemologies held in their indigenous languages in their research work. In so doing, students have opportunities to critique different knowledge systems in their languages and those in English, and vice versa. It is through these critical processes that students learn and theorise their new knowledge.

- Mary's pedagogical practices suggest that teachers may be able to facilitate students to translanguage without knowing their indigenous languages. This is a useful input for teachers and lecturers in IC countries where English is the medium of instruction and where there are students from diverse linguistic backgrounds-especially for those who do not know how to use their students' languages as resources for classroom practices when the teacher does not speak the students' languages. 
- Mary's Global South translanguaging practices provide useful pedagogical implications for English-as-a-medium-of-instruction (EMI) programs in higher education in OC and EC contexts. Lecturers in these programs can have students translanguage between English and their indigenous languages (including knowledge systems encoded in these languages) to facilitate their content knowledge development. It should be noted that the answers to questions, such as when to use which language, need further research-based evidence to confirm and are classroom/context specific. The use of genre pedagogy suggests that in EMI programs students' development in English proficiency is more than just having students familiarize with a set of vocabulary which is commonly found in particular disciplines. Genre pedagogy offers students opportunities to develop a functional understanding of text structures and their specific linguistic features in order to function in different modes of communication in their disciplines [47].

In summary, sàng khôn and Global South translanguaging are attributes of mobility education in globalisation. Sàng khôn contributes to students' agency and resources for personal becoming. Mary's pedagogical practices are empirical evidence to show how students' sàng khôn can be deployed as theorising tools in their knowledge construction [3,17]. These are much-needed practices to contribute to the contestation of English-only pedagogy and a shift in multilingual education in mobility education [3].

Acknowledgments: I wish to express my sincere thanks to Barbara Comber, Michael Singh, Jenny Barnett, Jill Burton and the anonymous reviewers for their constructive comments on my previous drafts. The remaining errors are my own.

Conflicts of Interest: The author declares no conflict of interest.

\section{References}

1. Singh, M.; Huang, X. Bourdieu's lessons for internationalising Anglophone education: Declassifying Sino-Anglo divisions over critical theorising. Comp. A J. Comp. Int. Educ. 2013, 43, 203-223. [CrossRef]

2. Singh, M.; Lu, S. Post-monolingual demystification of critical thinking: Advancing intercultural divergences in education. In Demystifying Critical Thinking in Multilingual and Intercultural Education; Dervin, F., Clark, J., Eds.; Palgrave Macmillan: Basingstoke, UK, 2017; in press.

3. Singh, M. Next-generation researchers' theorising global mobility education. In Symposium for Re-valuing Service Learning and Outward-bound Mobility Experiences through University Institutionalisation of 21st Century Educational Practices; 2016; unpublished paper.

4. Swain, M.; Kirkpatrick, A.; Cummins, J. How to Have A Guilt-Free Life Using Cantonese in the English Class: A Handbook for the English Language Teacher in Hong Kong. Available online: https://www.ied. edu.hk/rcleams/handbook/handbook.pdf (accessed on 22 August 2016).

5. García, O.; Wei, L. Translanguaging: Language, Bilingualism and Education; Palgrave Macmillan: Basingstoke, UK, 2014.

6. Heugh, K. Epistemologies in multilingual education: Translanguaging and genre-companions in conversation with policy and practice. Lang. Educ. 2015, 29, 280-285. [CrossRef]

7. Wei, L. Translanguaging (language) learning in a multilingual and multimodal world. In Proceedings of the ALAA/ALANZ/ALTAANZ 2015 Conference: Learning in a multilingual world, Adelaide, Australia, 30 November-2 December 2015.

8. Singh, M.; Harreveld, B.; Gao, T.; Danaher, P. Mobility and Local/International Knowledge Co-Production. In Mobile Teachers, Teacher Identity and International Schooling; Arber, R., Blackmore, J., Vongalis-Macrow, A., Eds.; Sense Publishers: Rotterdam, The Nertherlands, 2014; pp. 121-139.

9. Auerbach, E.R. Reexamining English Only in the ESL Classroom. TESOL Q. 1993, 27, 9-32. [CrossRef]

10. Phillipson, R. Linguistic Imperialism; Oxford University Press: Oxford, UK, 1992.

11. Grosjean, F. Neurolinguists, beware! The bilingual is not two monolinguals in one person. Brain Lang. 1989, 36, 3-15.

12. Pennycook, A. Rethinking Origins and Localization in Global Englishes. In Contending with Globalization in World Englishes; Saxena, M., Omoniyi, T., Eds.; Multingual Matters: Bristol, UK, 2010. 
13. Institute of International Education. Project Atlas. Available online: http://www.iie.org/Research-andPublications/Project-Atlas/About (accessed on 20 August 2016).

14. Australian Education International. International Student Data. Available online: https://internationaleducation. gov.au/research/International-Student-Data/Documents/MONTHLY\%20SUMMARIES/2016/06_June_ 2016_MonthlySummary.pdf (accessed on 20 August 2016).

15. Times Higher Education. The World University Ranking. Available online: https://www. timeshighereducation.com/world-university-rankings/2016/world-ranking\#!/page/0/length/50/ sort_by/rank_label/sort_order/asc/cols/rank_only (accessed on 22 August 2016).

16. The British Council. The English Effect. Available online: https://www.britishcouncil.org/sites/default/ files/english-effect-report-v2.pdf (accessed on 22 August 2016).

17. Singh, M. Worldly Critical Theorizing in Euro-American Centered Teacher Education? Preparing Bilingual Teacher-Researcher Theorists for the Twenty-First Century. In Preparing Teachers for the 21st Century; Zhu, X., Zeichner, K., Eds.; Springer: Berlin/Heidelberg, Germany, 2013; pp. 141-169.

18. Singh, P.; Doherty, C. Global Cultural Flows and Pedagogic Dilemmas: Teaching in the Global University Contact Zone. TESOL Q. 2004, 38, 9-42. [CrossRef]

19. Singh, M. Urban education across the post-colonial, post-cold war South Pacific: Changes in the trans-national ordering of theorisingUrban education across the post-colonial, post-cold war South Pacific: Changes in the trans-national ordering of theorising. In International Handbook of Urban Education; Noblitt, G., Pink, W., Eds.; Springer: Dordrecht, The Nerterlands, 2017; in press.

20. Nightingale, A.W. On Wandering and Wondering: "Theôria" in Greek Philosophy and Culture. Arion A J. Humanit. Classics 2001, 9, 23-58.

21. Tran, L.T.; Marginson, S. Education for Flexibility, Practicality and Mobility. In Higher Education in Vietnam: Flexibility, Mobility and Practicality in the Global Knowledge Economy; Palgrave Macmillan: London, UK, 2014; pp. 3-25.

22. Phan, V.N. Tục ngũu, ca dao, dân ca Việt Nam, 8th ed.; Thời Đại: Hà Nội, Viet Nam, 2010.

23. Dũng, B.V. Triết lý vế giáo dục trong thành ngũo, tục ngũ Việt Nam. Tạp chí Khoa học xã hội Việt Nam $2013,7,7$.

24. Norton, B.; Williams, C.J. Digital identities, student investments and eGranary as a placed resource. Lang. Educ. 2012, 26, 315-329. [CrossRef]

25. Gonzalez, N.; Moll, L.; Amanti, C. Funds of Knowledge: Theorizing Practices in Households and Classrooms; Taylor\&Francis: Hoboken, NJ, USA, 2009.

26. Moll, L.; Amanti, C.; Neff, D.; Gonzalez, N. Funds of knowledge for teaching: Using a qualitative approach to connect homes and classrooms. In Funds of Knowledge: Theorizing Practices in Households and Classrooms; Gonzalez, N., Moll, L., Amanti, C., Eds.; Taylor\&Francis: Hoboken, NJ, USA, 2009; pp. 71-87.

27. Gonzalez, N.; Moll, L.; Amanti, C. Introduction: Theorising practices. In Funds of knowledge: Theorizing practices in Households and Classrooms; Taylor\&Francis: Hoboken, NJ, USA, 2009; pp. 1-24.

28. Cummins, J. The Construct of Language Proficiency in Bilingual Education. In Current Issues in Bilingual Education; Alatis, J., Ed.; Goergetown University Press: Washington, DC, USA, 1980; pp. 81-103.

29. Cummins, J. Fundamental psycholinguistic and sociological principles underlying educational success for linguistic minority students. In Social Justice through Multilingual Education; Skutnabb-Kangas, T., Phillipson, R., Mohanty, A.K., Panda, M., Eds.; Channel View Publications: Clevedon, UK, 2009; pp. 19-35.

30. García, O.; Kleyn, T. (Eds.) Translanguaging with Multilingual Students: Learning From Classroom Moments; Routledge: New York, NY, USA, 2016.

31. Baker, C.; Jones, S.P. Encyclopedia of bilingualism and bilingual education; Multilingual Matters: Clevedon, UK; Philadelphia, PE, USA, 1998.

32. García, O.; Kleyn, T. Translanguaging Theory in Education. In Translanguaging with Multilingual Students: Learning From Classroom Moments; García, O., Kleyn, T., Eds.; Routledge: New York, NY, USA, 2016; pp. $17-37$.

33. Baker, C. Foundations of Bilingual Education and Bilingualism (Bilingual Education E Bilingualism), 5th ed.; Hornberger, N., Baker, C., Eds.; Multilingual Matters: Bristol, UK, 2011.

34. Canagarajah, S. Codemeshing in Academic Writing: Identifying Teachable Strategies of Translanguaging. Modern Lang. J. 2011, 95, 401-417. [CrossRef]

35. Holliday, A. Native-speakerism. ELT J. 2006, 60, 385-387. [CrossRef]

36. Braine, G. Nonnative Speaker English Teachers; Routledge: New York, NY, USA, 2010. 
37. Kachru, B. Opening borders with world Englishes: Theory in the classroom. In On JALT96: Crossing Borders; The Japan Association for Language Teaching (JALT): Hiroshima, Japan, 1996.

38. Doan, N.B. English as an international language (EIL): Relationship to English studies in the Asia-Pacific region. Ph.D. Thesis, The University of South Australia, Magill, Australia, June 2012.

39. Ha, P.L. Toward a critical notion of appropriation of English as an international language. Asian EFL J. 2005, 7, 34-36.

40. Auerbach, E.R. Reflections on Auerbach (1993), “Reexamining English Only in the ESL Classroom”. TESOL Q. 2016, 50, 936-939. [CrossRef]

41. Derewianka, B.; Jones, P. Teaching Language in Context; Oxford University Press: Melbourne, Australia, 2012.

42. Usó-Juan, E.; Martínez-Flor, A. Teaching Intercultural Communicative Competence through the Four Skills. Revista Alicantina de Estudios Ingleses 2008, 21, 157-170. [CrossRef]

43. Connell, R. Using southern theory: Decolonizing social thought in theory, research and application. Plan. Theory 2014, 13, 210-223. [CrossRef]

44. Connell, R. The Northern Theory of Globalization. Sociol. Theory 2007, 25, 368-385. [CrossRef]

45. Connell, R. Southern Theory: The Global Dynamics of Knowledge in Social Science; Polity: Cambridge, UK, 2007.

46. Singh, M.; Rizvi, F.; Shrestha, M. Student mobility and the spatial production of cosmopolitan identities. In Spatial Theories of Education: Policy and Geography Matters; Gulson, K.N., Symes, C., Eds.; Routledge: London, UK; New York, NY, USA, 2007; pp. 195-214.

47. Mahboob, A. English medium instruction in higher education in Pakistan: Policies, perceptions, problems, and possibilities. In English as A Medium of Instruction in Higher Education in Asia-Pacific: From Policy to Pedagogy; Fenton-Smith, B., Humphreys, P., Walkinshaw, I., Eds.; Springer: Cham, Switzerland, 2017.

(C) 2017 by the author; licensee MDPI, Basel, Switzerland. This article is an open access article distributed under the terms and conditions of the Creative Commons Attribution (CC BY) license (http:/ / creativecommons.org/licenses/by/4.0/). 